\title{
Mean Maximum Mixing Heights for Northern Asia for the Winter of 1978
}

W. E. Davis

P. E. Tucker

August 1984

Prepared for the U.S. Air Force under a Related Services Agreement with the U.S. Department of Energy

Contract DE-AC06-76RLO 1830

Pacific Northwest Laboratory

Operated for the U.S. Department of Energy by Battelle Memorial Institute 


\title{
DISCLAIMER
}

This report was prepared as an account of work sponsored by an agency of the United States Government. Neither the United States Government nor any agency thereof, nor any of their employees, makes any warranty, express or implied, or assumes any legal liability or responsibility for the accuracy, completeness, or usefulness of any information, apparatus, product, or process disclosed, or represents that its use would not infringe privately owned rights. Reference herein to any specific commercial product, process, or service by trade name, trademark, manufacturer, or otherwise, does not necessarily constitute or imply its endorsement, recommendation, or favoring by the United States Government or any agency thereof. The views and opinions of authors expressed herein do not necessarily state or reflect those of the United States Government or any agency thereof.

\author{
PACIFIC NORTHWEST LABORATORY \\ operated by \\ BATTELLE \\ for the \\ UNITED STATES DEPARTMENT OF ENERGY \\ under Contract DE-AC06-76RLO 1830
}

\begin{tabular}{|c|c|}
\hline \multirow{2}{*}{\multicolumn{2}{|c|}{ Printed in the United States of America }} \\
\hline & \\
\hline \multicolumn{2}{|c|}{$\begin{array}{l}\text { Available from } \\
\text { National Technical Information Service }\end{array}$} \\
\hline \multicolumn{2}{|c|}{$\begin{array}{l}\text { National Technical Information Service } \\
\text { United States Department of Commerce }\end{array}$} \\
\hline \multirow{2}{*}{\multicolumn{2}{|c|}{$\begin{array}{l}5285 \text { Port Royal Road } \\
\text { Springfield, Virginia } 22161\end{array}$}} \\
\hline & \\
\hline \multirow{2}{*}{\multicolumn{2}{|c|}{$\begin{array}{l}\text { NTIS Price Codes } \\
\text { Microfiche A01 }\end{array}$}} \\
\hline & \\
\hline \multicolumn{2}{|c|}{ Printed Copy } \\
\hline Pages & $\begin{array}{l}\text { Price } \\
\text { Codes }\end{array}$ \\
\hline $001-025$ & $A 02$ \\
\hline $026-050$ & $\mathrm{~A} 03$ \\
\hline 051-075 & A04 \\
\hline 076-100 & A05 \\
\hline $101-125$ & A06 \\
\hline $126-150$ & A07 \\
\hline $151-175$ & $\mathrm{~A} 0 \mathrm{~B}$ \\
\hline $176-200$ & $A 09$ \\
\hline $201-225$ & A010 \\
\hline 226-250 & A011 \\
\hline $251-275$ & A012 \\
\hline 276-300 & A013 \\
\hline
\end{tabular}


MEAN MAXIMUM MIXING HEIGHTS

FOR NORTHERN ASIA FOR THE

WINTER OF 1978

W. E. Davis

P. E. Tucker

August 1984

Prepared for the U.S. Air Force Under a Related Services Agreement with the U.S. Department of Energy Contract DE-AC06-76RLO 1830

Pacific Northwest Laboratory Richland, Washington 99352 
Mean maximum mixing heights are used to compute the vertical extent of mixing of an air pollutant released in the surface boundary layer. A past study by Holzworth (1972) has examined mean maximum mixing heights in the United States. This study was confined to northeastern Asia and presents the results of computing maximum mixing heights over a single winter. Also included are mean layer-averaged wind speeds for the same time period. Two regions of low maximum mixing heights and low mean wind speeds were noted. 


\section{CONTENTS}

\begin{tabular}{|c|c|c|c|c|c|c|c|c|c|c|c|}
\hline SUMMARY & - & - & - & - & - & - & - & - & - & - & - $i i i$ \\
\hline INTRODUCTI & ION & - & - & - & - & - & - & - & - & - & • \\
\hline TECHNIQUE & - & - & - & - & . & - & - & - & . & - & • \\
\hline DATA BASE & - & - & - & - & - & - & - & - & - & - & . \\
\hline RESULTS & - & - & • & - & - & $\cdot$ & - & - & - & - & • \\
\hline REFERENCES & & - & - & - & - & - & • & - & $\cdot$ & - & - \\
\hline APPENDIX & $A--S$ & ATION & LOCAT & TIONS & • & - & - & - & - & - & - A. 1 \\
\hline APPENDIX & $B--M$ & NTHLY & MEAN & MIXI & & IIGHTS & - & - & - & - & - B. 1 \\
\hline
\end{tabular}




\section{FIGURES}

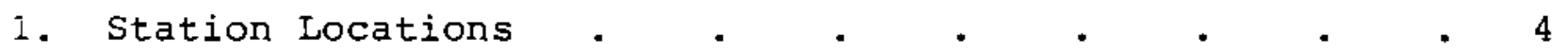

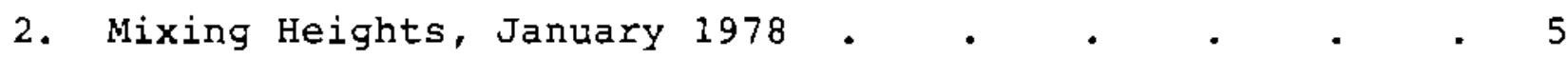

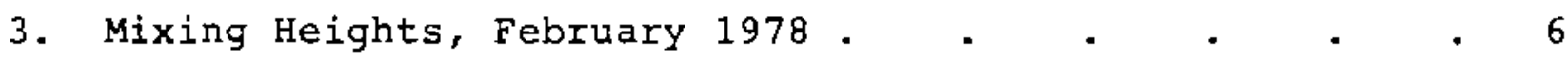

4. Mixing Heights, March 1978 . $\quad$. $\quad . \quad$. $\quad . \quad$. 6

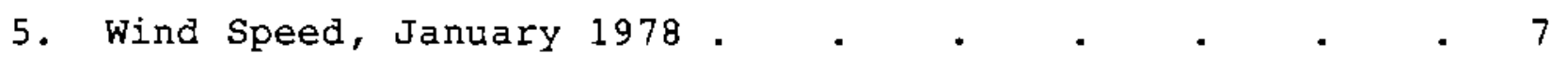

6. Wind Speed, February 1978 . $\quad . \quad$. $\quad . \quad$. $\quad .7$

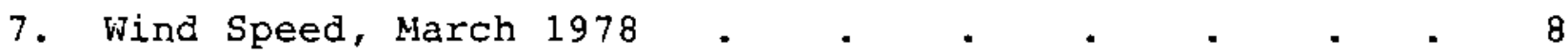


MEAN MAXIMUM MIXING HEIGTHS FOR NORTHERN ASIA

FOR THE WINTER OF 1978

\section{INTRODUCTION}

One of the parameters affecting the estimation of surface air concentrations of a pollutant is the mean maximum mixing height. Studies of the mean maximum mixing height have been made for the United States by Holzworth (1972). To date no studies have been made of northeastern Asia. Northern Asia is of particular interest in computing maximum mixing heights since this region receives very little solar radiation during the winter. The effect is that the surface will receive little or no solar insolation. With a decrease in heating at the surface, the maximum mixing height will decrease. These low maximum mixing heights combined with low wind speeds will cause a high potential for high surface air concentrations of pollutants. Since this region is under the influence of high pressure, one would expect low maximum mixing heights and low wind speeds would occur in regions of a low-pressure gradient thereby producing a high potential for aix pollution (Holzworth 1972).

To determine maximum mixing heights we used the method developed by Holzworth (1972) with some modifications. One necessary modification was due to the assumption that the morning sounding should be used with the afternoon maximum temperature to compute the maximum mixing depth. Our application used the maximum temperature whenever it occurred within the solar day. Also, no allowance was made for an increase in mixing height due to precipitation. The following provides a brief description of the technigue used, a description of the data base followed by the results. Two appendixes have been included providing data for individual stations. 


\section{TECHNIQUE}

Two pieces of information need to be computed before a region can be designated as having a high potential for air pollution. These are a low maximum mixing height and low wind speeas. The maximum mixing height is the maximum height to which a surface parcel may penetrate vertically. The technique used to find this maximum height was, first, to find the time of maximum sur face temperature and, second, to compute a potential temperature. Potential temperature is calculated by the following equation.

$$
\theta=T\left(\frac{1000}{\mathrm{P}}\right){ }^{0.2857}
$$

where: $P=$ pressure in millibars

$$
\mathrm{T}=\text { temperature (absolute) in }{ }^{\circ} \mathrm{K} \text {. }
$$

Once the potential temperature was found, the vertical temperature sounding was used to find the greatest height above the surface where the surface potential temperature intersected the vertical potential temperature profile. This height was designated as the maximum mixing height.

Once the mean maximum mixing height is known, the mean wind speeds also must be calculated. The mean wind speeds were computed using vertical profiles of wind speeds and directions. Rather than computing mean wind speeds over the complete maximum mixed height, separate layer-averaged values for 100 to $500 \mathrm{~m}$ and for 500 to $1000 \mathrm{~m}$ above the surface were computed. Using two layers will allow some examination of wind shear in regions where the mixing layer extends above $500 \mathrm{~m}$. 
DATA BASE

The data base used for this study is the USAFETAC DATSAV data base provided by the U.S. Air Force. Both surface and upper-air data sets were accessed (USAFETAC 1977).

The months selected for the study were January, February and March 1978. This selection was made on the basis of comparisons of mean surface temperatures (Lydolph 1977) at sites throughout northern Asia.

During these months the mean temperatures generally ran normal to two degrees above normal. The upper-air stations used in this study are shown in Figure 1. A list of the stations and their locations is included in Appendix A. It is important to note that the density of stations is somewhat sparse in the extreme northern areas. The quality of data emanating from these stations was poor. Therefore, results in these regions could be improved if additional data were available.

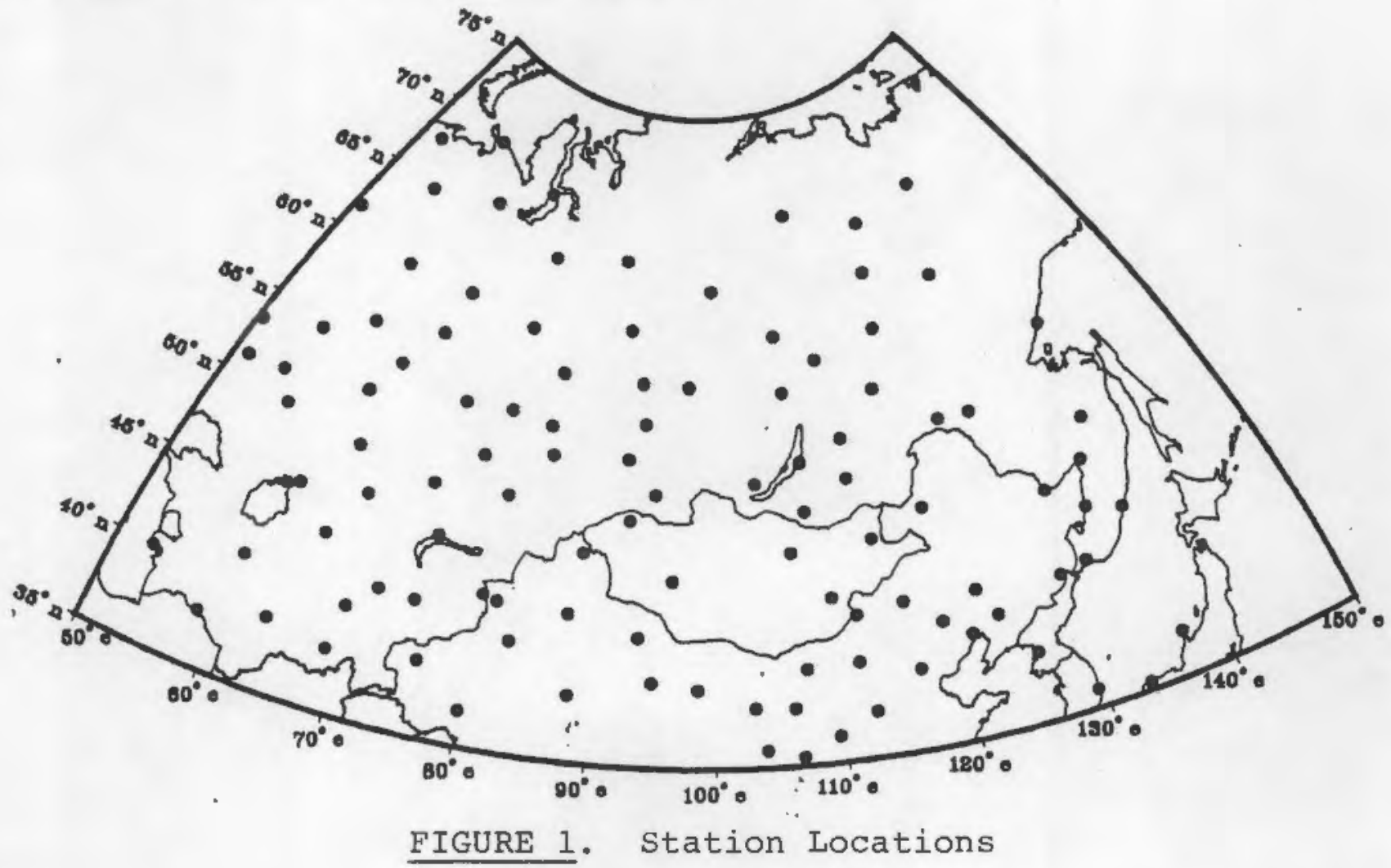




\section{RESULTS AND CONCLUSIONS}

A comparison of surface temperatures during the 1978 study period indicated the mean values were normal to $2^{\circ} \mathrm{C}$ above normal for most of the stations. A comparison of surface maps indicated, in general, a normal occurrence of high-pressure systems in Northern Asia during the period of study. This would indicate the results found in this study may be expected for other winters.

The results for the maximum mixing heights have been summarized in Figures 2, 3 and 4 and in Appendix B. Figures 5, 6 and 7 show the mean velocity for a layer 100 to $500 \mathrm{~m}$ above surface. The combination of the two sets can provide insight into regions where low mixing heights and low winds would tend to create regions with high potential for air pollution (Holzworth 1972).

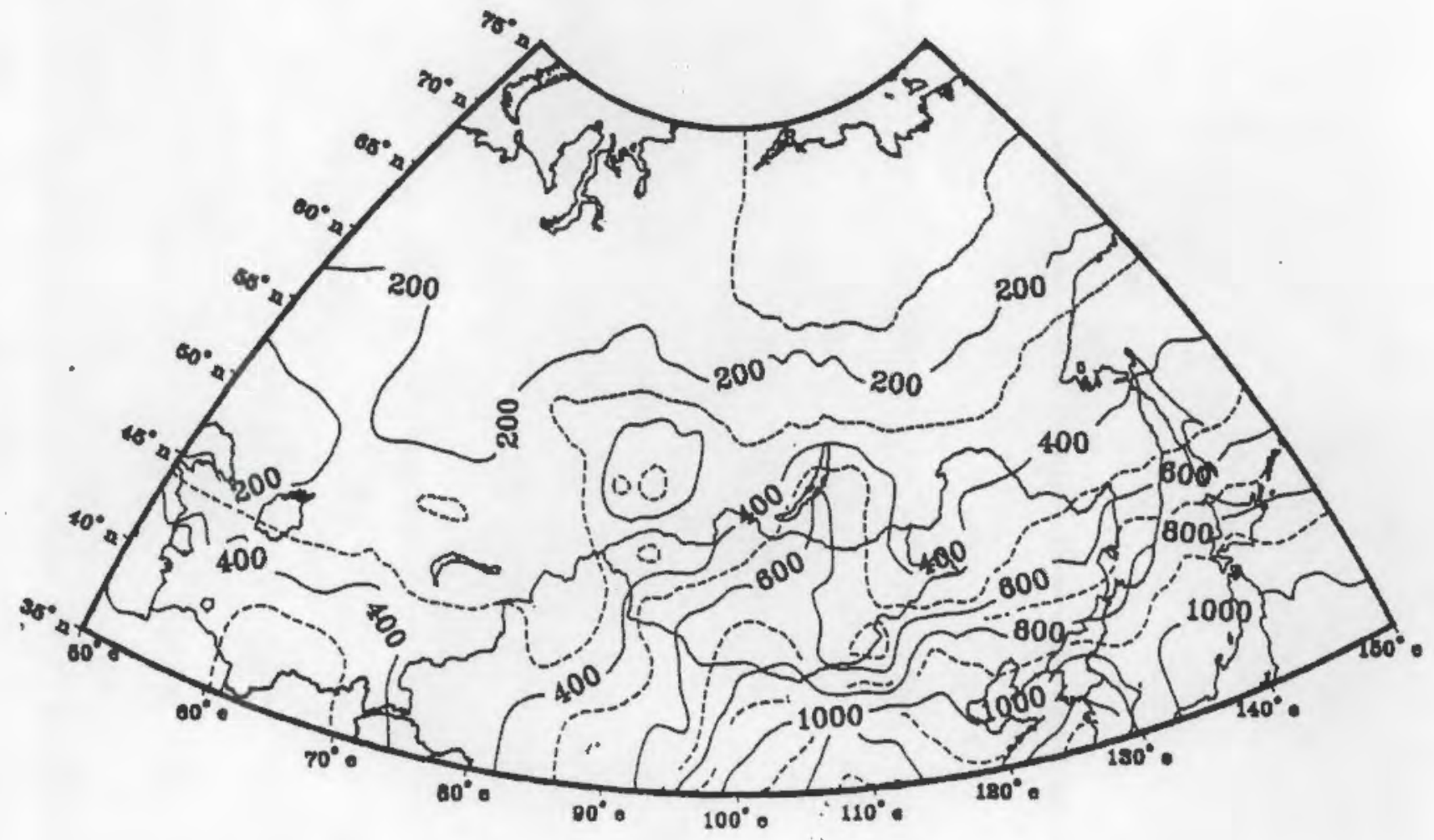

FIGURE 2. Mixing Heights (m), January 1978 


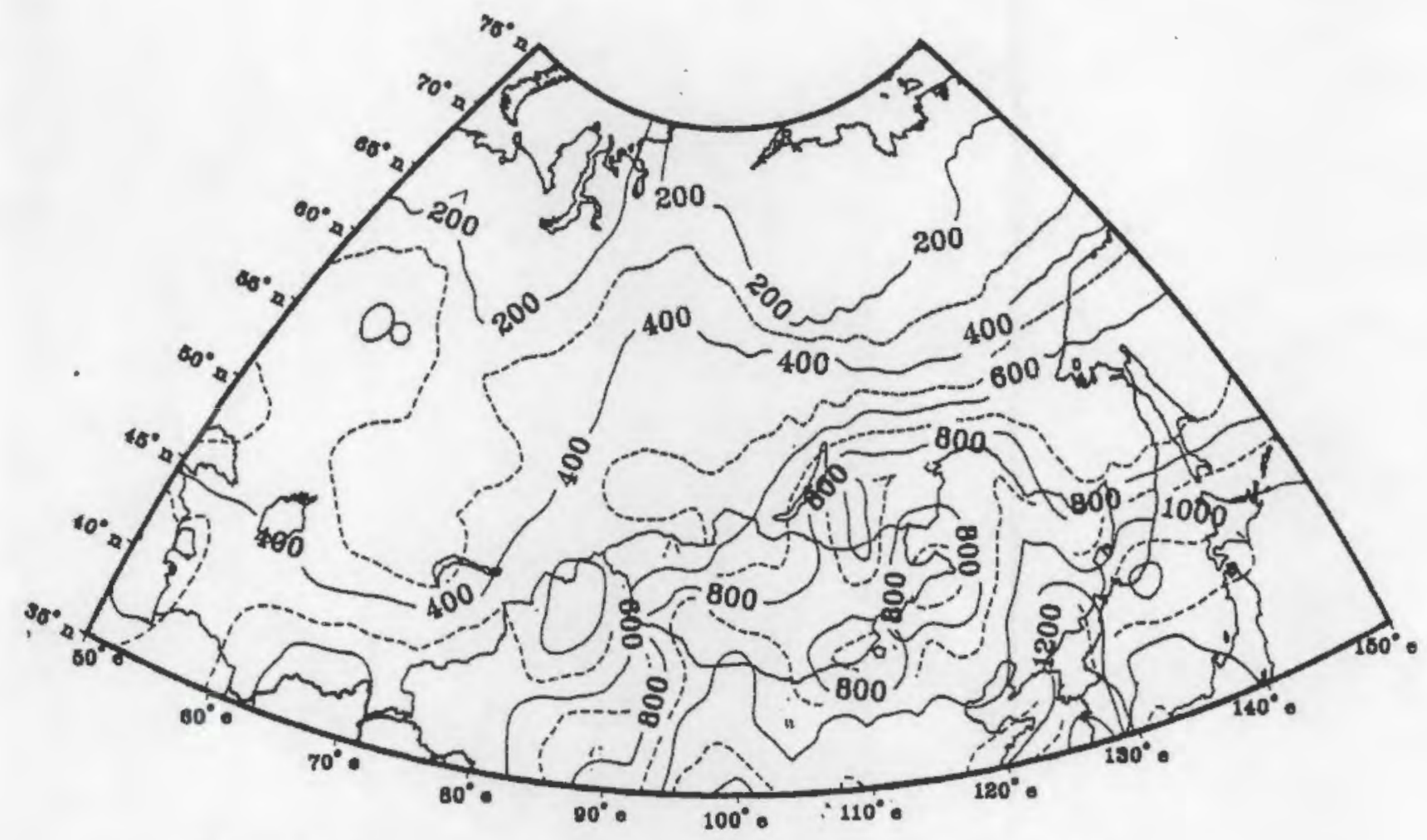

FIGURE 3. Mixing Heights (m), February 1978

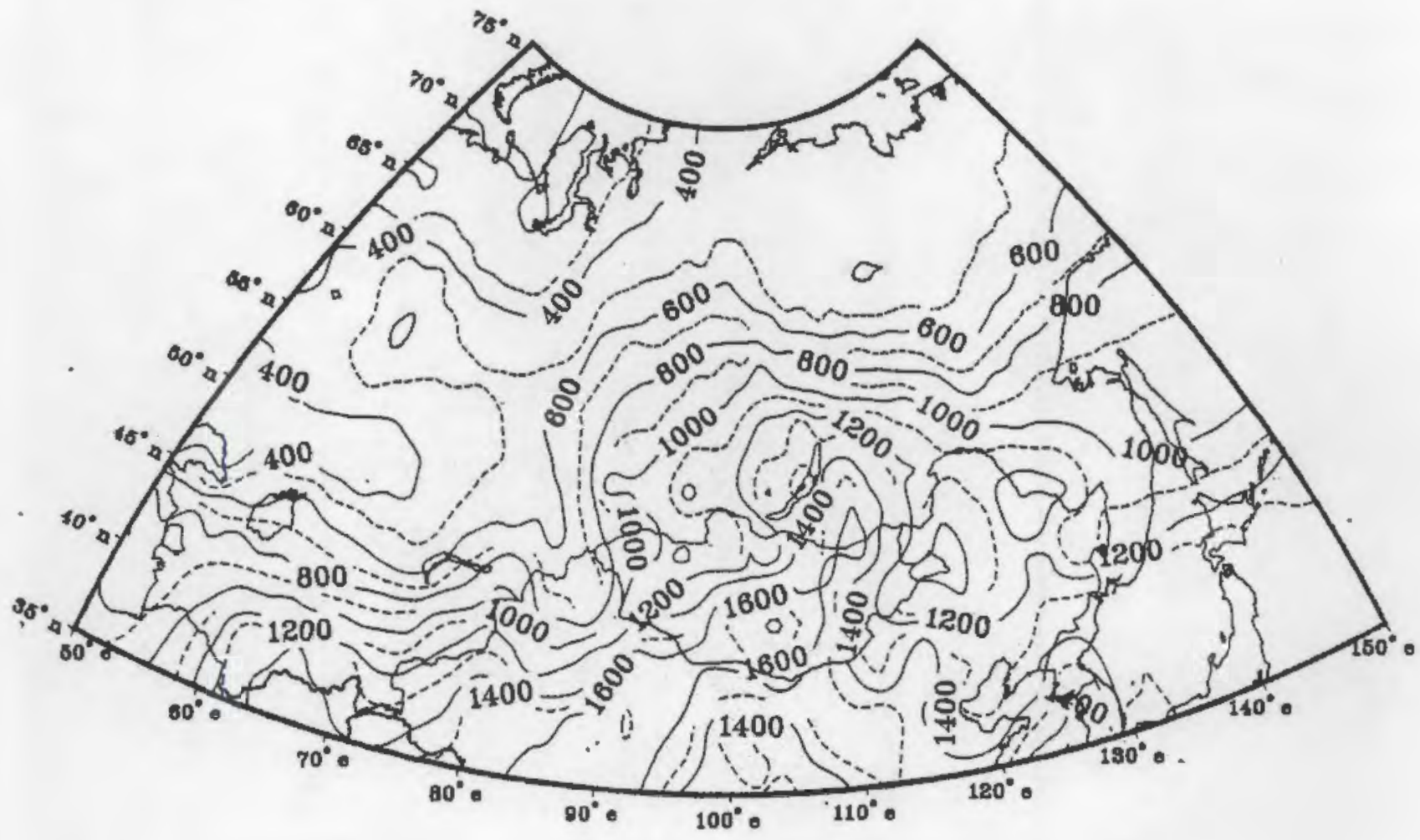

FIGURE 4. Mixing Heights (m), March 1978 


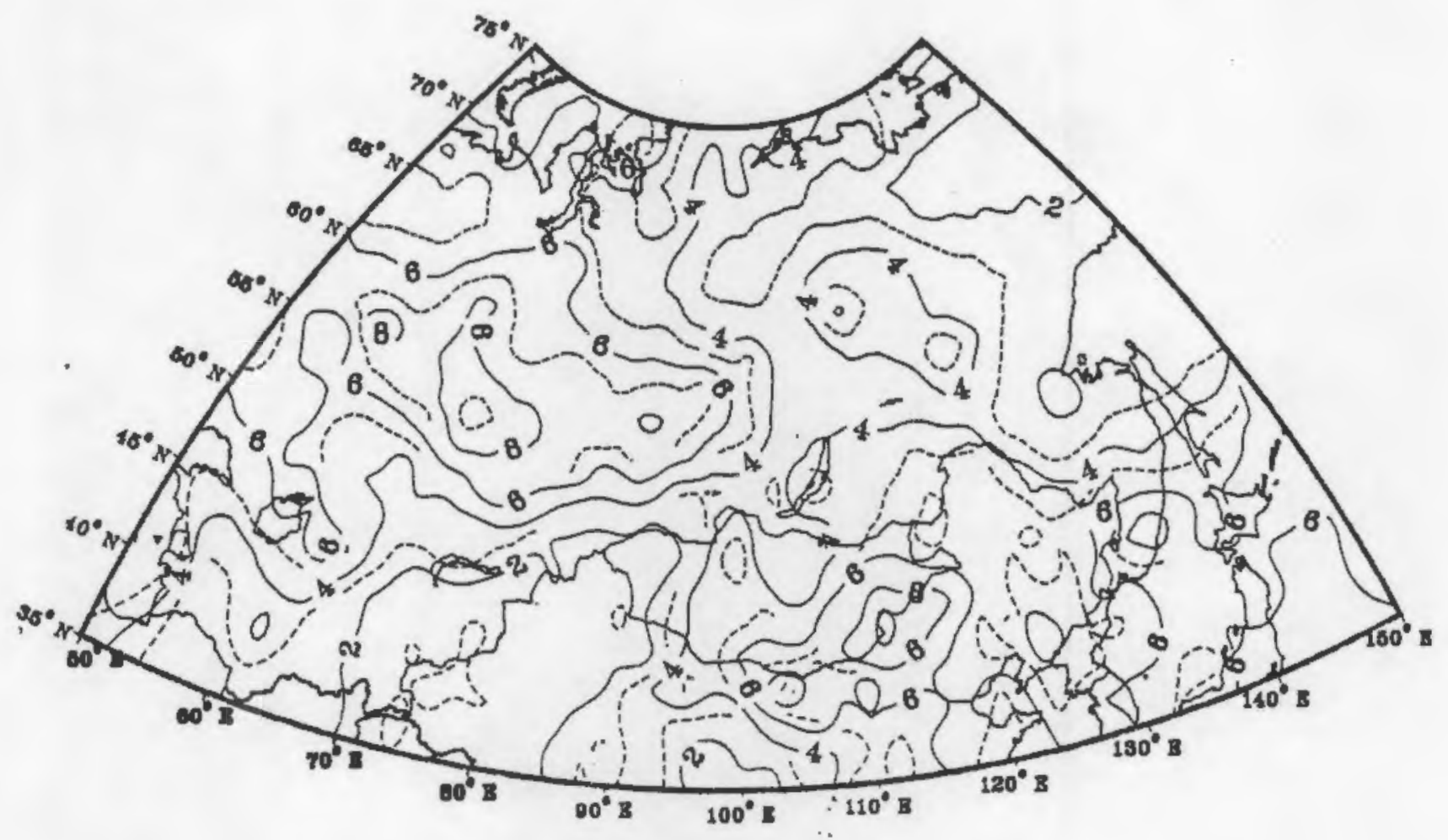

FIGURE 5. Wind Speed (m/s), January 1978

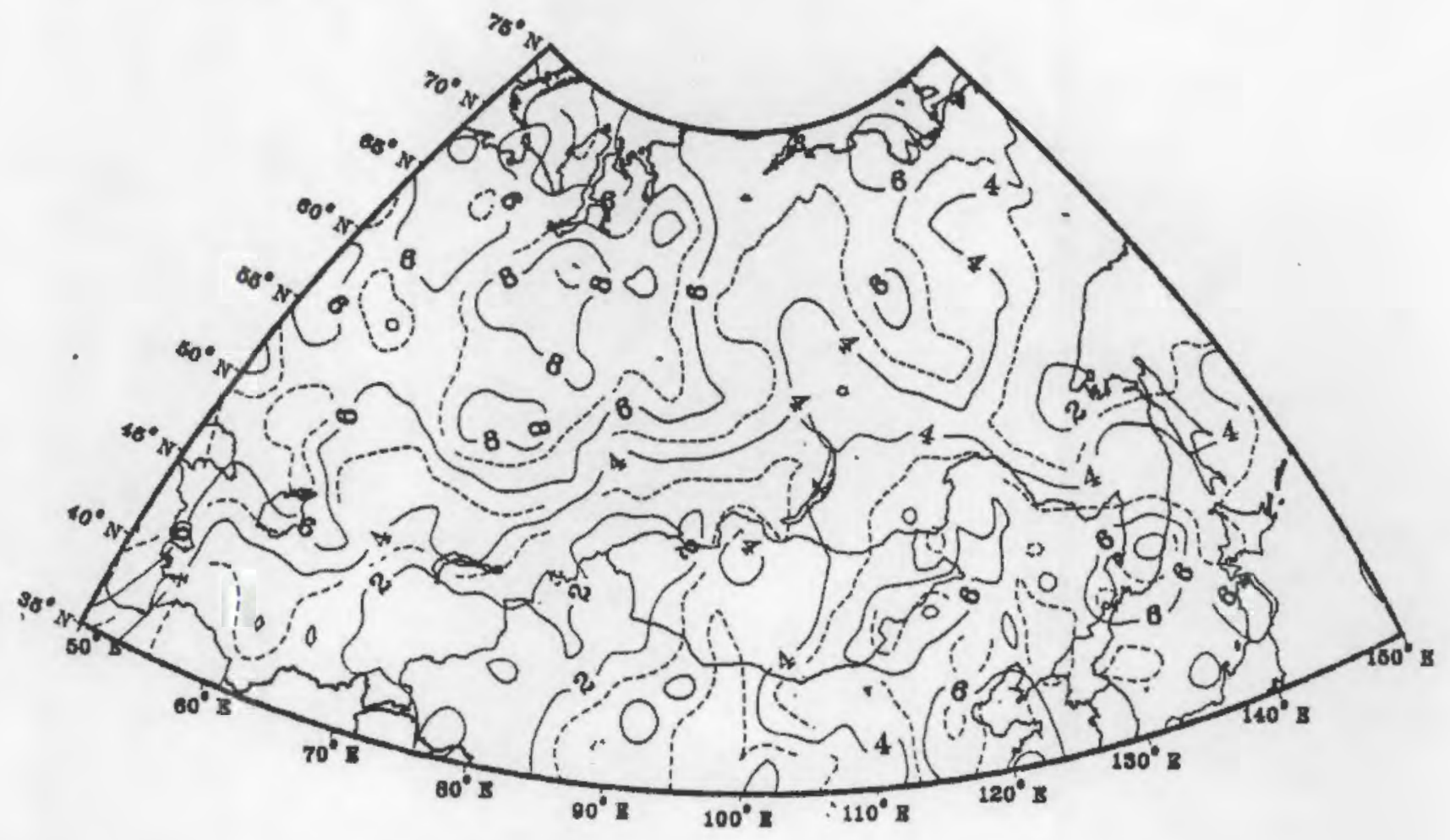

FIGURE 6. Wind speed (m/s), February 1978 


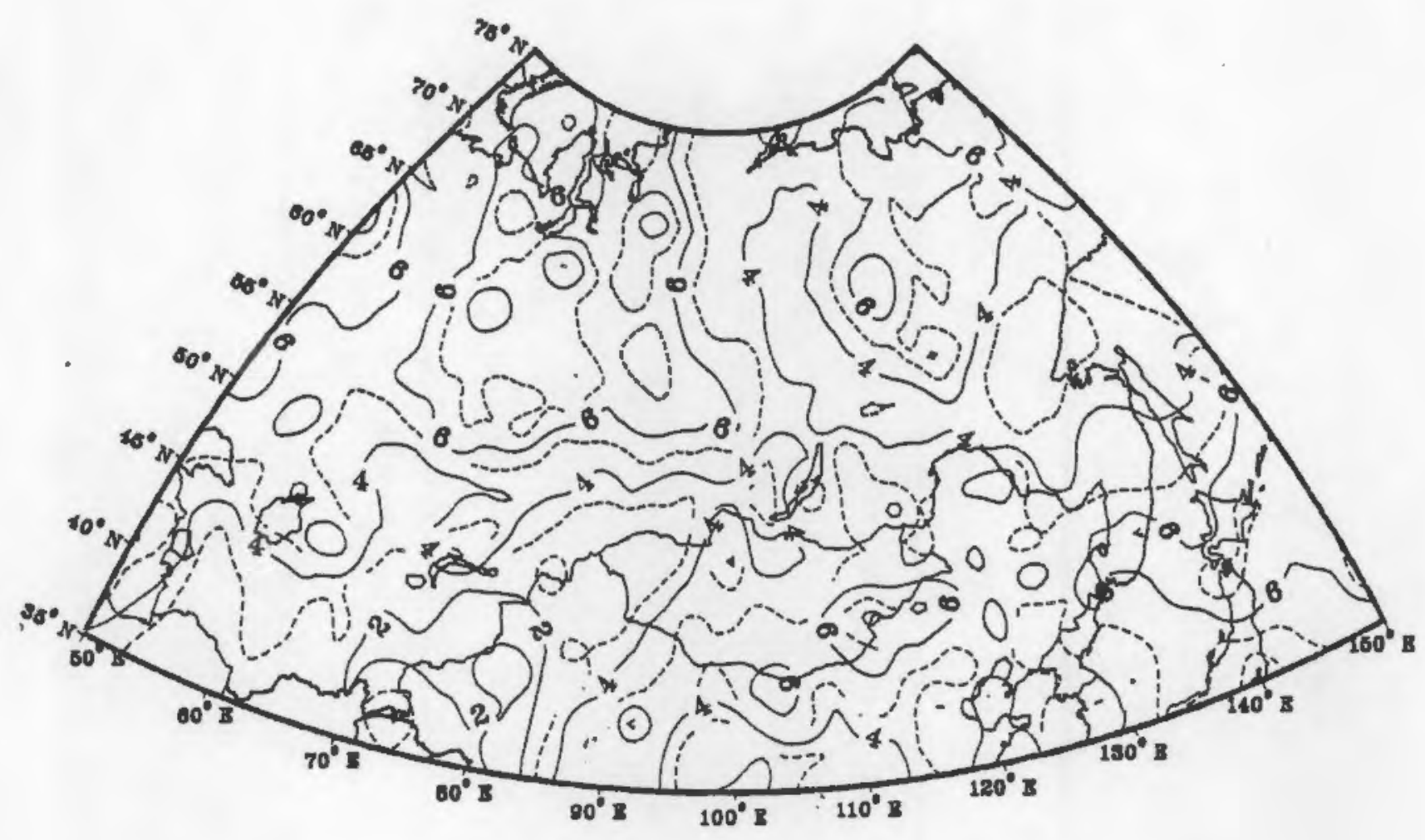

FIGURE 7. Wind Speed (m/s), March 1978

Two regions were found that have low mixing heights and low wind speeds. The first is the northeastern USSR with maximum mixing heights no greater than $200 \mathrm{~m}$ and a mean wind speed under $2 \mathrm{~m} / \mathrm{s}$ for January. The second region is the sikiang province in China with mixing heights less than $200 \mathrm{~m}$ and mean wind speed under $2 \mathrm{~m} / \mathrm{s}$. By March, a rather dramatic change occurred as the height for the northeastern USSR increased 300 to $400 \mathrm{~m}$ above surface and the wind speed increased 4 to $6 \mathrm{~m} / \mathrm{s}$. In Sikiang the wind speed generally remained near $2 \mathrm{~m} / \mathrm{s}$; however, the maximum mixing height increased to 1000 to $1600 \mathrm{~m}$ above surface. In both cases, the air pollution potential would have decreased from January to March 1978 . 


\section{REFERENCES}

Holzworth, G. C. 1972. Mixing Heights, Wind Speeds, and Potential for Urban Air Pollution Throughout the Contiguous United States. Environmental Protection Agency, Raleigh, North Carolina.

Lydolph, P. E. 1977. Climates of the Soviet Union. Vol. 7. Elsevier Scientific Publishing Company, New York, New York.

USAFETAC. 1977. DATSAV Data Base Handbook. U.S. Air Force, Scott AFB, Illinois. 
APPENDIX A

STATION LOCATIONS 


\section{APPENDIX A}

\section{STATION LOCATIONS}

\begin{tabular}{|c|c|c|c|c|c|}
\hline $\begin{array}{l}\text { STATION } \\
====:=\end{array}$ & $\begin{array}{l}\text { LA\}ITLE } \\
\text { =F==2x }\end{array}$ & $\begin{array}{l}\text { LQNGITUDE } \\
x==x===\end{array}$ & $\begin{array}{l}\text { STATION } \\
=====\end{array}$ & 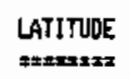 & $\begin{array}{l}\text { LONGITODE } \\
\text { =:==-= }\end{array}$ \\
\hline 230220 & 69.7 & -61.70 & 313000 & 53.75 & -127.25 \\
\hline 230780 & 69.32 & -68.29 & 315100 & 50.27 & -127.52 \\
\hline 231460 & 68.47 & -73.62 & 315380 & 50.07 & -132.15 \\
\hline 292050 & 67.65 & -53.03 & 315510 & 50.60 & -137.10 \\
\hline 233380 & 66.53 & -66.55 & 317070 & 47.73 & -130.90 \\
\hline 234180 & 65.12 & -57.12 & 317350 & 48.52 & -135.18 \\
\hline 234720 & 65.79 & -87.97 & 318730 & 45.93 & -133.73 \\
\hline 235520 & 64.92 & -77.83 & 319090 & 45.05 & -136.63 \\
\hline 238049 & 61.67 & - دئ & 319600 & 43.12 & -131.92 \\
\hline 238949 & 61.60 & $-90,02$ & 351080 & 31.25 & -51.42 \\
\hline 239210 & 60.68 & -60.45 & 351210 & 51.75 & -55.12 \\
\hline 239330 & 60.97 & -69.08 & 352250 & 50.28 & -57.17 \\
\hline 239550 & 64.49 & -77.88 & 353519 & 50.17 & -65.22 \\
\hline 291250 & 68.50 & -112.45 & 353940 & 49.80 & -73.15 \\
\hline 242660 & 67.55 & -133.40 & 396710 & 47.80 & -67.73 \\
\hline 243430 & 66.77 & -123.42 & 357460 & 46.78 & $-61,68$ \\
\hline 245070 & 64.28 & -100.25 & 357960 & 46.90 & -75.02 \\
\hline 246410 & 63.77 & -121.63 & 360030 & 52.28 & -76.97 \\
\hline 248170 & 61.27 & -108.03 & 360960 & 31.67 & -94.46 \\
\hline 249080 & 60.33 & -102.28 & 361770 & 50.35 & -60.27 \\
\hline 249440 & 60.40 & -120.43 & 368590 & 44.17 & -80.08 \\
\hline 249590 & 62.98 & -129.77 & 300620 & 14.77 & -65.55 \\
\hline 28225: & 58.02 & -5.32 & 383410 & 42.85 & -71.40 \\
\hline 282750 & 58.15 & -68.20 & 383530 & 42.83 & -74.60 \\
\hline 284400 & 55.80 & -60.65 & 383920 & 41.83 & -60.00 \\
\hline 286610 & 55.47 & -65.42 & 304130 & 41.73 & -64.63 \\
\hline $2 B 6980$ & 54.93 & -73.42 & 384570 & $\$ 1.27$ & $-69.2 B$ \\
\hline 297220 & 54.82 & -56.17 & 395070 & 40.03 & -53.00 \\
\hline 289000 & 53.25 & -50.47 & 386060 & 40.55 & -70.97 \\
\hline 289520 & 59.22 & -53.53 & 386870 & 39.08 & -63.62 \\
\hline 292310 & 58.30 & -62.92 & 389360 & 38.58 & -68.80 \\
\hline 292630 & 58.45 & -92.17 & 398900 & 37.97 & -58.35 \\
\hline 292820 & 50.30 & -97.50 & 407450 & 36.27 & -59.65 \\
\hline 295740 & 56.00 & -92.98 & 442120 & 49.97 & -92.10 \\
\hline 296120 & 55.37 & -78.42 & 442310 & 49.69 & -100.10 \\
\hline 296340 & 55.03 & -62.92 & 142590 & 48.07 & -114.52 \\
\hline 296980 & 54,88 & -99.05 & $\$ 42770$ & 46.40 & -96.27 \\
\hline 298390 & 59.33 & -83.72 & 442920 & 47.93 & -107.00 \\
\hline 299658 & 53.75 & -91.42 & 443540 & 44.90 & -110.13 \\
\hline 306540 & 59.45 & -112.60 & 443730 & $43.5 B$ & $-104,43$ \\
\hline 302300 & 57.77 & -108.13 & 470410 & 39.93 & -127.57 \\
\hline 303090 & 56.30 & -101.72 & 470580 & 39.03 & -125.80 \\
\hline 303720 & 56.92 & -118.27 & 471380 & 36.03 & -129.40 \\
\hline 305210 & 54.80 & -105.18 & 476000 & 37,38 & -136.92 \\
\hline 305540 & 54.47 & -113.50 & 477446 & 35.43 & -133.37 \\
\hline 306350 & 53.43 & -109.00 & 505270 & 49.22 & -119.77 \\
\hline 306730 & 53.73 & -119.80 & 510760 & 47.79 & -60.10 \\
\hline 306920 & 54.00 & -123.99 & 514310 & 43.95 & -81.35 \\
\hline 307100 & 52.37 & -104.20 & 514630 & 43.90 & -87.48 \\
\hline 307586 & 52.02 & -113.35 & 516440 & 41.72 & -82.97 \\
\hline 309350 & 50.37 & -108.77 & 517090 & 39.47 & -76.00 \\
\hline 399650 & 50.39 & -116.53 & 517770 & 39.03 & -89.18 \\
\hline 311680 & 56.45 & -138.17 & 518280 & 37.13 & -79.95 \\
\hline
\end{tabular}

\begin{tabular}{|c|c|c|}
\hline $\begin{array}{l}\text { STATIWN } \\
===\div= \pm=\end{array}$ & $\begin{array}{l}\text { LATITUDE } \\
\text { =A土s=:= }\end{array}$ & $\begin{array}{l}\text { LQNGITUDE } \\
\text { :=E:=:=E }\end{array}$ \\
\hline 522030 & 42.82 & -93.53 \\
\hline 522670 & 41.99 & $-\$ 01.08$ \\
\hline 524190 & 40.13 & -94.80 \\
\hline 525350 & 39.77 & -98.53 \\
\hline 526810 & 38.62 & -103.12 \\
\hline 528890 & 36.95 & -103.90 \\
\hline 530680 & 43.65 & -112.02 \\
\hline 534630 & 40.82 & -111.70 \\
\hline 535130 & 40.77 & -107.42 \\
\hline 535140 & $30, A B$ & -106.23 \\
\hline 597720 & 37.78 & -112.57 \\
\hline 538450 & 36,60 & -109.52 \\
\hline 539150 & 33.55 & -106.68 \\
\hline 541020 & 43.95 & -116.00 \\
\hline 541350 & 43.60 & -122.28 \\
\hline 542189 & $\$ 2.27$ & -118.98 \\
\hline 542920 & 42.88 & -129.48 \\
\hline 543370 & 41.13 & -121.13 \\
\hline $549 \div 20$ & 41.82 & -123.57 \\
\hline 545110 & 39.80 & $-116.4 B$ \\
\hline
\end{tabular}




\section{APPENDIX B}

MONTHLY MEAN MIXING HEIGHTS 


\section{APPENDIX B}

\section{MONTHLY MEAN MIXING HEIGHTS}

Mean mixing heights for each station during the months used in the study are listed. The days in the month where mixing occurred are tabulated under the column heading "NM." The column "NS" tabulates those days in each menth where data was available but conditions were not appropriate for calculating mixing depths. The third column "NO" contains the count of the days during the month when data were not available at the station. 


\section{Mean Monthly Mixing Heights in Meters}

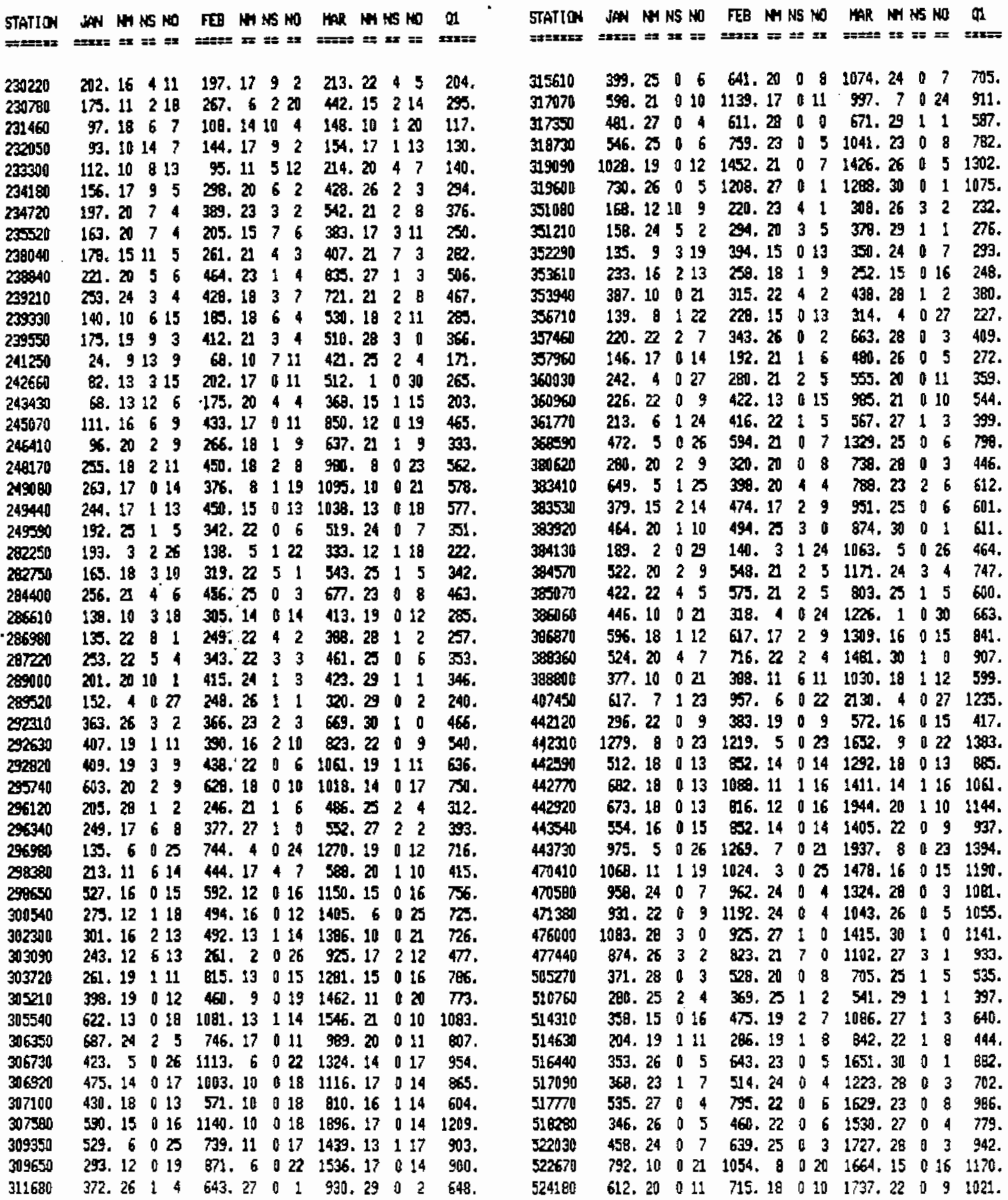




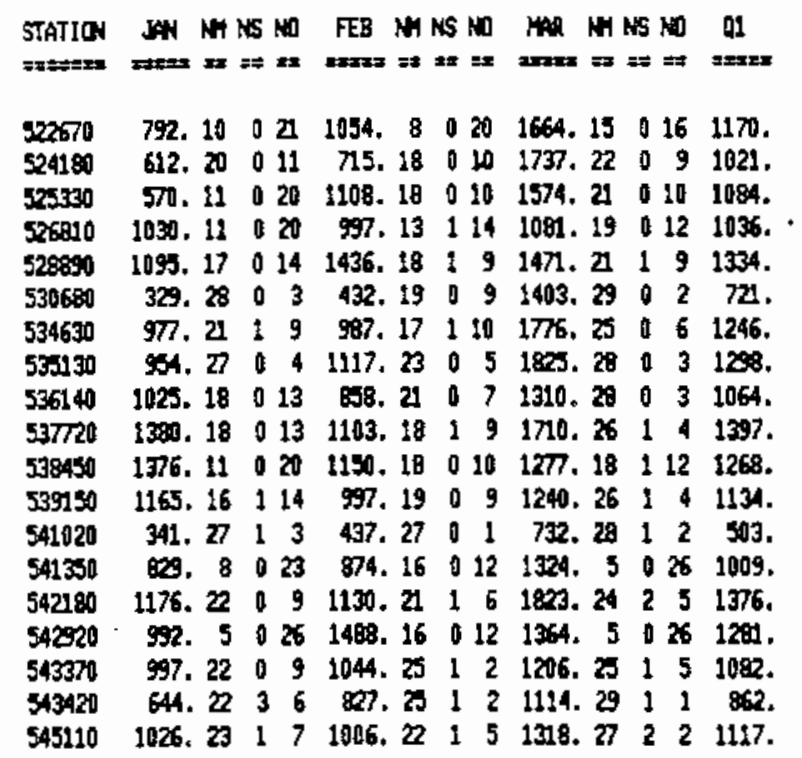




\section{DISTRIBUTION}

No. of

Copies

OFFSITE

DOE Division of Biomedical and Environmental Research washington, DC 20545

27 DOE Technical Information Center

S. Barr

Environmental Studies Group

MS-D 466

Los Alamos National Laboratory

P.O. Box 1663

Los Alamos, NM 87545

W. Clements

Los Alamos National Laboratory

P.O. Box 1663

Los Alamos, NM 87545

T. Crawford

Savannah River Laboratory

E. I. Du Pont de Nemours and Company, Inc.

Aiken, SC 29801

G. A. Cowan

University of California

Los Alamos National Laboratory

P.O. Box 1663

Los Alamos, NM 87545

lst Lt. L. Davis
AFTAC/TN Headquarters $1035^{\text {th }}$ TOG

Patrick AFB, FL 32925

D. Doda

ENSCO, Inc.

1930 Highway AlA

Indian Harbor Beach, FL 32937
No. of

Copies

R. Draxler

National Oceanic \& Atmospheric Administration

Silver Springs, MD 20910

F. Gifford

Consultant

Los Alamos National Laboratory

P.O. Box 1663

Los Alamos, NM 87545

C. Hatley

ENSCO, Inc.

1930 Highway AlA

Indian Harbor Beach, FL 32937

J. Heffter

National Oceanic \& Atmospheric Administration

Silver Springs, MD 20910

A. Jaffey

Argonne National Laboratory

9700 South Cass Avenue

Argonne, IL 60439

J. Knox

Division Leader, Atmospheric and Geophysical Sciences

University of California

P.O. Box 808

Livermore, CA 84550

T. Kyle

Los Alamos National Laboratory P.O. Box 1663

Los Alamos, NM 87545 
No. of

Copies

L. Machta

National Oceanic \& Atmospheric Administration

Silver Springs, MD 20910

J. Pitkethly

ENSCO, Inc.

1930 Highway AlA

Indian Harbor Beach, FL 32937

A. Siegel

ENSCO, Inc.

Data and Computer section

1930 Highway A1A

Indian Harbor Beach, FL 32937

F. Tingey

1826 Sequoia

Idaho Falls, ID 83401

H. D. Tolley

Brigham Young University

226 TMCB

Provo, UT 84602
No. of

Copies

A. Turkevich

University of Chicago

Enrico Fermi Institute

5640 S. Ellis Avenue

Chicago, IL 60637

ONSITE

DOE Richland Operations

office

H. E. Ransom

17 Pacific Northwest Laboratory

W. E. Davis (3)

D. L. Hall

R. E. Kleinknecht

W. L. Nicholson

A. R. Olsen

P. E. Tucker (2)

L. L. Wendell

Publishing Coordination (2)

Technical Information (5) 